\title{
Deleterious PPP2R2A Gene Mutation
}

National Cancer Institute

\section{Source}

National Cancer Institute. Deleterious PPP2R2A Gene Mutation. NCI Thesaurus. Code C134509.

A change in the nucleotide sequence of the PPP2R2A gene that is associated with increased risk of disease. 